\title{
The Personification of the Nature in the Novel "Sweet Salt of Bosphorus" By E. Safarli
}

\section{Bryk Marina Murmanovna ${ }^{1}$}

PhD Candidate, National Pedagogical Dragomanov University,

$$
\text { Kyiv, Ukraine. }
$$

(date of receiving: April, 2019; date of acceptance: November, 2019)

\begin{abstract}
In modern linguistics much attention is paid to the studying of the concept. Being a key term of many linguistic areas, the concept has become the main subject of cognitive linguistics, lingvoculturology and one of the newest streams - lingvoimagology. Our research deals with the studying of the concept "Nature" and one of the ways of its verbalization in the literary text - personification. Both intellectual and emotional spheres of a person participate in the process of creation of the personification. It contributes to the understanding of the images of the surrounding world, which is very important for perception of a literary text containing writer's individual vision of different processes and phenomena. Analyzing examples of personification used by the writer gives the possibility to make conclusions about morphological and syntactical structure of this stylistic device and key features which create its basis. The research of stylistic means and devices is especially important in terms of modern literature, because nowadays writers create special language style which must be carefully studied.
\end{abstract}

Keywords: Lingvoimagology, Concept, Personification, Personification Structure.

1. E-mail: marina212012@rambler.ru 


\title{
Олицетворение природы в романе Э.Сафарли «Сладкая соль Босфора»
}

\section{Брык Марина Мурмановна ${ }^{1}$}

Аспирант кафедры общего языкознания и германистики, Национального педагогического университета им. М.П. Драгоманова, Киев, Украина.

(дата получения: апрель 2019 г.; дата принятия: ноябрь 2019 г.)

\begin{abstract}
Аннотация
В современном языкознании значительное внимание уделяется изучению концепта. Данный термин является ключевым для ряда областей лингвистической науки, включая когнитивную лингвистику, лингвокультурологию и одно из новейших направлений - лингвоимагологию. В нашем исследовании мы рассмотрим концепт «Природа» и олицетворение как средство его вербализации. В процедуре создания эффекта олицетворения задействованы эмоциональная и интеллектуальная сферы человека. Это способствует пониманию образов окружающего мира и дает возможность пропускать их через чувства и эмоции, что является важным для понимания литературного произведения, в котором заложено индивидуально-авторское видение тех или иных процессов и явлений. Анализ примеров использования автором олицетворения дает возможность сделать выводы о морфолого-синтаксической структуре данного тропа и о ключевых признаках, на основе которых он строится. Особенно актуальными является исследование данного тропеического средства на материале современной прозы, поскольку сегодня писатели создают особенный языковой стиль, который нуждается во всестороннем лингвистическом исследовании.

Ключевые слова: Лингвоимагология, Концепт, Языковая Картина Мира, Олицетворение, Персонификация, Олицетворяющая Структура.
\end{abstract}

1. E-mail: marina212012@rambler.ru 


\section{Введение}

Метафорическое осмысление природы имеет древние традиции, поскольку человек с самого начала своего существования был взаимосвязан с ней. Приближенность к природе повлияла на формирование духовного мира человека. Природные явления и объекты являлись предметами поклонения, наделяясь магическими свойствами.

В основе большей части художественных образов природы лежит троп олицетворения, с помощью которого ее объекты и явления наделяются человеческими качествами. Благодаря антропоморфным свойствам природа в литературных произведениях становится не только ключом к пониманию авторского мировосприятия и инструментом передачи эмоциональных состояний, но и полноправным персонажем, включенным в сюжетную структуру и способным оказывать на ее влияние. По справедливому замечанию М. Эпштейна, природа в литературе не просто «эстетическое своеобразие» словесного произведения искусства, но и «система устойчивых мотивов» (Эпштейн 1990. 34).

В данной статье мы исследуем олицетворяющие структуры в романе «Сладкая соль Босфора», которые применяются Э. Сафарли при создании образов природных явлений и объектов, выделяя их грамматические особенности и свойства, на которых они строятся.

\section{Основная часть}

Исследование природы попадает в поле интересов многих
фундаментальных наук и становится составляющей различных видов
искусств. Для современных направлений лингвистики является актуальным
изучение природы в виде концепта. В настоящее время термин концепт
находит применение в различных областях лингвистической науки:


когнитивистики, лингвокультурологии, лингвоимагологии. Согласно данным наукам, концепт является ключевой единицей языковой картины мира. В настоящее время наиболее полное исследование языковой картины мира возможно в рамках лингвоимагологии.

Лингвоимагология - новое синтезирующее направление, которое разрабатывается профессором Л.П. Ивановой и включает в себя «отдельные аспекты и категории когнитивной лингвистики, лингвокультурологии, теории текста, теории коммуникации, прагмалингвистики» (Иванова 2013. 144).

Термин «концепт» в лингвоимагологии рассматривается как элемент художественного осмысления мира, потому для раскрытия его значения используем определение Ю.С. Степанова: «концепт - это как бы сгусток культуры в сознании человека: то, в виде чего культура входит в ментальный мир человека» (Степанов 1995. 30).

В процессе воплощения концепта в художественном тексте важная роль принадлежит образным средствам языка. Предметом нашего исследования являются олицетворения в рамках концепта «Природа» в романе Э. Сафарли «Сладкая соль Босфора».

По мнению И.Б. Голуб, «олицетворением называется наделение неодушевленных предметов признаками и свойствами человека. Олицетворение - один из самых распространенных тропов. Традиция его употребления восходит к устной народной поэзии. Художники слова сделали олицетворение важнейшим средством образной речи. Олицетворения используются при описании явлений природы, окружающих человека вещей, которые наделяются способностью чувствовать, мыслить, действовать» (Голуб 2010. 135).

Особым видом олицетворения следует считать персонификацию. Персонифицированные предметы и явления обретают реальный человеческий облик. 
Статус олицетворения не определен однозначно в лингвистической науке. Много трудов посвящено исследованию данного стилистического приема (Е.А. Бахмутова, Ю.А. Бельчиков, А.И. Гудавичюс, Н.О. Гучинская, М.А. Зозуля, А.П. Квятковский, В.П. Ковалев, Е.А. Некрасова, С.С. Парсамов и др.).

Несмотря на распространенность олицетворения в художественных текстах и наличие характерных отличительных черт, данный прием часто трактуется как всего лишь один из видов метафоризации (Е.А. Бахмутова, М.А. Зозуля, В.П. Ковалев, Е.А. Орлова, Е.А. Тихомирова и др.) или как форма аллегории (Ю.А. Бельчиков, Н.О. Гучинская).

В исследованиях лингвистов, посвященных изучению грамматических и стилистических особенностей художественного приема олицетворения, отмечается многообразие языковых средств его выражения в тексте. Особенности тропа описываются в связи с идиостилем конкретного писателя или со спецификой жанра произведения.

В нашем исследовании под олицетворением понимаем ассоциативное перенесение внешних признаков и эмоциональных черт человека на предметы и явления природы.

Наша структурная классификация олицетворений базируется на типологии С.К. Константиновой (Константинова 2005). В основу типологии положены морфолого-синтаксические признаки, учитывающие место олицетворения в синтаксической структуре предложения или текста, принадлежность к частям речи и синтаксические функции олицетворяющих слов. Таким образом, основными грамматическими структурами, содержащими олицетворение, являются предикативные двучленные синтагмы, атрибутивные двучленные синтагмы, дистанционное олицетворение, развернутый олицетворяющий контекст и олицетворяющее сравнение.

Проанализируем олицетворения в пределах концепта «природа» в романе «Сладкая соль Босфора» современного русскоязычного писателя Эльчина 
Сафарли. Данный художественный прием применяется автором в следующих фрагментах:

\section{Стихии}

\section{Босфор}

Босфор в ответ кивает. В качестве приветствия сонное утреннее море посылает в ответ волну - пенистую, шипучую (Сафарли 2017. 8);

Он - верный, чувственныгй, постоянный - всегда готов прийти на помощь. Только позови. Если осень обижают, Босфор рвет и мечет. (...) Он знает - осень виноватой быть не может (Сафарли 2017. 11);

Поэтому нанесенные ей обиды Босфор не прощает. Он любит осень (Сафарли 2017. 11);

Он ненавидит осадки, так как в такую погоду люди его не посещают. Ведь, по сути, Босфор одинок с тех пор, как дельфинь покинули пролив... (Сафарли 2017. 24);

Босфор бесится от злости - за утро громадные волны потопили два судна в бухте (Сафарли 2017. 44);

Босфор добрый, щуедрый, красивый и ну очень романтичный... (Сафарли 2017. 48);

В полнолуние мой романтичный друг с нетерпением ждет гостей. Он боится оставаться наедине с луной (Сафарли 2017. 56);

«Я слишком самодостаточен, чтобы повиноваться ей...» (Сафарли 2017. 56);

Когда Босфор злится, он становится еще более очаровательным (Сафарли 2017. 56);

За окном дремал вечерний Босфор ... (Сафарли 2017. 82);

Мои слезы вытирает Босфор (Сафарли 2017. 222). 
На основе приведенных примеров можем сделать вывод о том, что среди грамматических конструкций, содержащих олицетворение пролива Босфор, наибольшей частотностью использования обладает двучленная предикативная синтагма. В качестве слов, которые содержат в себе олицетворяющий признак, выделяем глаголы действия: кивает, прийти, вытирает, называет; глаголы состояния: ждет, дремал. Особое место занимают глаголы эмоционального отношения: не прощчает, любит, ненавидит, бесится, боится, дуется, возмущается, не терплю, верит, злится. Эмоциональное состояние Босфора передается и с помощью фразеологизма рвет $u$ мечет. Количественное превосходство глаголов эмоционального отношения (10 из 16 ) свидетельствует о стремлении автора максимально «очеловечить» Босфор, чему способствуют и следующие имена прилагательные: верный, чувственный, постоянньій, одинок, добрый, щедрый, романтичный, самодостаточен, отважен, мудрый. Данные лексемы характеризуют Босфор как «личность» и входят в состав атрибутивных двучленных синтагм.

В словосочетании Босфор с нетерпением ждет выделяем предикативную двучленную синтагму + олицетворяющую предложно-падежную форму имени существительного.

Э. Сафарли акцентирует внимание и на внешних признаках Босфора, давая им оценку:

Босфор добрый, щеедрый, красивый ... (Сафарли 2017. 4).

Приобретенный Босфором человеческий облик позволяет автору выделять такие признаки как части тела и мимика:

Недовольная гримаса сменяется прежним спокойствием. Подхожу к нему ближе, крепко обнимаю. Шепчу на ухо: «Ты не такой, как все. Ты удивителен. Ты всегда с нами. И мы всегда с тобой!..» (Сафарли 2017. $57)$; 
«... Ведь таким образом я отдаляюсь от берега. Берега, где ты, Айдынлыг, и ещче много моих друзей», - дуется Босфор, хмурясь, как обиженный ребенок (Сафарли 2017. 56).

Обратим внимание на сравнительный оборот «как обиженный ребенок». Будучи олицетворяющим сравнением, данная конструкция содержит эксплицированную субъективно-модальную оценку персонификации описываемого объекта.

Особенностью образа пролива Босфор является наделение его возможностью говорить. В тексте встречаем несколько примером прямой речи Босфора, в которую также включены олицетворяющие признаки:

Босфор возмущается пуще прежнего: «Ты издеваешься?! Лучше бы подсказал, как загнать злюку за толстые облака. Мне не больно. Просто не терплю, когда мною помыкают!» (Сафарли 2017. 56);

Босфор по-юношески отважен. Уверенно называет себя свободным. «Быть свободным - значит верить в собственные желания. Многие из них кажутся неосуществимыми. Так кажется. Просто надо сделать первый шаг. Дальше, легче... Быть свободным - значит никогда не жалеть. Быть свободным - значить желать, добиваясь желаемого». Теория мудрого Босфора. Дни, месящь, года, века научили морского друга вере. Он верит, даже когда вьюга нагоняет пенистые волны... (Сафарли 2017. 170).

В тексте находим характеристику речи Босфора, дополняющую персонифицированный образ:

Издалека доносятся недовольное пыхтение Босфора (Сафарли 2017. 24). 
Олицетворяющий признак содержится в прилагательном, которое обозначает эмоцию, характерную для человека. Касательно имени существительного, номинирующего звук, создаваемый стихией, то он может быть характерным и для животного.

\section{Ветер}

Ветер в романе «Сладкая соль Босфора» также выступает денотатом олицетворения. Среди слов, содержащих олицетворяющие признаки, выделяем глаголы в составе предикативних двучленных синтагм:

умеет слушать, нащупьвает, вникает, отслеживает, умеет молчать, спешит поведать, иепчет.

Вопреки природной непостоянности он [ветер] умеет слушать нащуупьвает невидимыми руками эмоцуии, вникает в слова, внимательно отслеживает интонацию. И ещуе. Ветер умеет молчать (Сафарли 2017. $14)$;

... Магический ветерок города души преследует по пятам. Будто спешит о чем-то поведать крутится вокруг меня, шепчет непонятные заклинания, обдает ароматом розмарина. Он, как хвастливый ребенок, желающий продемонстрировать, чему научился (Сафарли 2017. 262).

При создании образа ветра автор снова использует олицетворяющее сравнение, в котором в качестве образа выступает ребенок, как и в случае с Босфором. Подобным в описании стихий является также выделение частей тела, в данном случае - руки.

В тексте, кроме общего образа ветра, встречаем и образы отдельных его видов.

Люблю их ощущать, прогуливаясь по набережной, где ветры разгульны, свободны, отважны (Сафарли 2017. 17); 
Несмотря на внешнюю агрессивность, внутри пойраз нежнозаботливый. С ним интересно говорить - он щееро делится харизмой (Сафарли 2017. 15);

Пойраз улыбается, говорит, что теплых слов не сльшал давно. «Люди думают, я злой... Поэтому отвечают мне злобно... Все, кроме тебя». Пьтаюсь разубедить его. Он делает вид, что верит... Пойраз слушает меня... (Сафарли 2017. 16);

Да и последний не обижается, когда сравнивают. «Я холодный-он теплый... Как нас можно сравнивать?» - ухмыляется пойраз (Сафарли 2017. 16);

Сначала он шипит, угрожает нависающими волнами, присматривается. Что поделаешь, недоверчив по природе... Но как только пойраз узнает в тепло одетом человеке «капусте» родного гостя, он успокаивается. Протягивает руку, крепко обнимает, вдыхает твой запах... (Сафарли 2017. 16);

...Когда в Стамбул приходит мельтем - сухой летний ветер, я покидаю город души. Признаюсь, из-за боязни перед мельтемом. Он жесток, беспощаден. Во всяком случае, для меня. Мельтем любит прошлое (Сафарли 2017. 17).

Для описания характера ветров Э. Сафарли применяет атрибутивные двучленные синтагмы со следующими именами прилагательными: разгульны, свободны, отважны, нежно-заботливый, недоверчив, любопытный, злой, жесток, беспощуаден. Предикативные синтагмы в своем составе имеют следующие типы глаголов: глаголы действия - делится, узнает, протягивает, обнимает, говорит; глаголы эмоционального отношения: не обижается, любит, угрожает, успокаивается, ульббается, верит, ухмыляется; глаголы чувственного восприятия - присматривается, вдыхает, слушает. Еще одна черта ветра представлена с помощью олицетворяющего наречия щзедро. Таким 
образом, пойраз с мельтемом обладают качествами человеческого характера, эмоциями и чувствами. На реальные очертания внешности указывает возможность установить тактильный контакт с ветром, наличие у него частей тела (протягивает руку), а также характеристики внешних особенностей поведения (делает вид, ухмыляется). Важным элементом персонифицированного образа, как и в случае с Босфором, считаем способность ветра «говорить» и наличие прямой речи данного персонажа в тексте.

Э. Сафарли использует олицетворяющие сравнения, в которых в качестве образов выступает как человек, так и животное (щееок-лабрадорчик).

Пойраз - как умный, успешный мужчина с нерасполагающей внешностью, но с тонкой душой (Сафарли 2017. 15);

Протягивает руку, крепко обнимает, вдыхает твой запах, как любопытный щеенок-лабрадорчик (Сафарли 2017. 16).

\section{Берег+море}

В тексте находим примеры персонификации звуков природы. Так, в следующем предложении олицетворяющий признак содержится в имени существительном ворковать - «издавать мягкие, гортанные звуки (о голубях). 2. Обычно шутл. Мягко, нежно говорить, разговаривать между собой» (Кузнецов 2000. 150).

Горячий песок, кричащие чайки в небе, воркование берега с морем...

(Сафарли 2017. 209).

\section{Волны}

Образ волн создается с помощью атрибутивной и предикативной синтагм с олицетворяющим прилагательным и глаголом: 
Разъяренные волны топят корабли, подводные течения разгоняют рыбешку (Сафарли 2017. 11);

Шум волн заглушает. Волны не хотят, чтобы ты услышала меня (Сафарли 2017. 222).

\section{Времена года}

\section{Осень}

Осень изображается с помощью олицетворяющего сравнения с девушкой, которое вводится словом похожа:

Она похожа на пышногрудую брюнетку, влюбленную в свободолюбивого моряка, которого преданно ждет (Сафарли 2017. 10);

При этом она [осень] за справедливость. Когда обижают молчит. Терпит. Выжидает. Как только обидчики забывают о сказанных словах, она, снимая маску безразличия, нападает (Сафарли 2017. 10).

Более подробные олицетворяющие признаки представлены следующими грамматическими конструкциями:

- предикативне двучленные синтагмы: осень ждет / за справедливость / молчит / терпит / выжидает / нападает.

- атрибутивные синтагмы: влюбленная

- олицетворяющий деепричастный оборот: снимая маску безразличия.

Персонифицированный образ дополняется также с помощью характера, который выделяет и описывает автор:

У нее (осени) характер мягкий, покладистый (Сафарли 2017. 11). 


\section{Животные}

\section{Кошки}

В романе «Сладкая соль Босфора» кошки сравниваются с богинями благодаря олицетворениию-приложению в составе атрибутивной двучленной синтагмы:

\footnotetext{
С двумя своими кошками - Гюльшен, Эбру. Подобрала их у подъезда дома. Из жалких худышек превратила в толстопузых богинь...
} (Сафарли 2017. 9);

Лохматые создания верны ему. Их не волнует, какая боль затаилась в душе... (Сафарли 2017. 71);

Мястам не остается в долгу. По утрам садится у подъезда, встречает выходящих. Приветливо виляет хвостом, напутственно мяукает. Желает удачи (Сафарли 2017. 263);

Сердие сентиментальной кошечки отдано рыжему коту с глазами разных ичветов (Сафарли 2017. 264).

Другие олицетворяющие признаки вводятся с помощью имен прилагательных верные, сентиментальные в составе атрибутивных двучленных синтагм; олицетворяющего наречия напутственно; предикативных двучленных синтагм кошка встречает / желает удачи.

\section{Собака}

Подобно кошкам, собака сравнивается с богиней с помощью перифразы: Длинноухая богиня уплетает печенье... (Сафарли 2017. 19).

Домашний питомец главного героя способен чувствовать и мыслить, что в тексте выражено глаголами любит, понимает, а также деепричастным оборотом осознавая собственную бесполезность: 
Айдынлыг тоже ждет, любит весну (Сафарли 2017. 49);

Айдынлыг лежит рядом. Навострила уши, виляет хвостом. Ликует.

Понимает: на линии - половинка сердияа хозяина (Сафарли 2017. 140);

Айдынльг, осознавая собственную бесполезность, разваливается под кухонным столом (Сафарли 2017. 241).

Автор описывает эмоции, которое испытывает животное, с помощью глагола (ликует) и наречия:

$$
\text { Айдынлыг останавливается перед разноиветными полями }
$$
тюльпанов, восхищенно лает (Сафарли 2017. 49).

Используя имена прилагательные (искренняя, добрая) в составе атрибутивной синтагмы и причастный оборот (верящяая в чудеса), автор характеризует «личность» Айдынлыг:

Айдынлыг - половинка моего сердйа. Половинка искренняя, добрая, верящзая в чудеса... (Сафарли 2017. 49).

\section{Дельфины}

Когда дует теплый лодоз, в Босфор запльвают дельфины. Жизнерадостные, игривые, немного настороженные. [...] Нет, они не в обиде на Босфор. Они в обиде на людей, загрязняющих Босфор (Сафарли 2017. 17).

Э. Сафарли, описывая морских жителей, применяет имена прилагательные с олицетворяющими признаками, а также предикативную синтагму (они не в обиде).

Маленькие дельфины имплицитно сравниваются с детьми, когда изображаются вовлеченными в детскую игру: 
... дельфинята затеяли чехарду недалеко от берега ... (Сафарли 2017. 82).

\section{Чайки}

Когда в городе души моросит дождь, чайки, вальсирующие над синеющим Босфором, громче кричат. В их глазах появляется смятение. Нет, они не боятся, что их привычную умиротворенность омрачат капли небесной воды. Все дело в преданности. Не хотят отлетать от Босфора, на время затаиться в соломенных убежищах. Чайки Стамбула сопровождают тебя на протяжении всей дороги жизни (Сафарли 2017. 6).

Вальсирующче чайки - атрибутивная двучленная синтагма, где олицетворяющий признак выражен причастием.

Чайки не боятся / не хотят / сопроваждают - предикативные двучленные синтагмы.

Такие душевные состояния, как смятение и умиротворенность, приписываются птицам с помощью дистантных олицетворений. Звуки, издаваемые чайками, олицетворяются с помощью следующего словосочетания:

... чайки пели кольбельную большому городу... (Сафарли 2017. 82).

\section{Голуби}

Образ голубей автор создает, привлекая олицетворяющее сравнение, где в качестве образа выступает человек:

Стая голубей окружила торговку, словно телохранители всеми любимого Сердара Ортаджа (Сафарли 2017. 32). 


\section{Журавли}

...Весну в Стамбул приносят журавли. Они - чуток усталье, с поблекшими перьями, глазами кофейного ияета - громким криком влетают в город души. Молодые журавлики шумят от радости. Пожилье журавли - сохраняют молчание. Когда сквозь бежевый туман они замечают Великий мост, то просто плачут. С глаз, наполненных темно-золотой водицей мудрости, стекают слезы. Слезы счастья. Весь долгий путь из Африки они мечтали добраться до Стамбула... (Сафарли 2017. 46);

Они отдыхали, беседовали с Босфором, рассматривали многочисленных голубей с легкой завистью во взгляде. Ведь им не надо куда-то улетать. "А у нас впереди еще перелет в Восточную Европу...» - сетовали журавли в беседе с друзьями-цаплями. Они жаловались, но в душе все равно оставались самыми счастливыми созданиями на свете... (Сафарли 2017. 47).

Автор изображает эмоции вестников весны с помощью:

- дистантных олицетворений с предложно-падежными формами имен существительных: от радости, с легкой завистью. К дистантным олицетворениям относим и словосочетание слезы счастья.

- предикативных двучленных синтагм с олицетворяющими глаголами плачут, мечтали, отдыхали, рассматривали. Отдельно выделим глаголы, благодаря которым персонифицируются звуки птиц: беседовали, сетовали, жаловались. Два последних глагола являются синонимами и отображают эмоциональный окрас беседы. Кроме этого, в ходе «беседы» автор вводит прямую речь журавлей.

- атрибутивной двучленной синтагмы с прилагательным yсталые. Вторым типом атрибутивной двучленной синтагмы является олицетворение-приложение друзья-цуапли. 
Развернутое олицетворение журавлей дополняется описанием глаз птиц с помощью определения наполненных темно-золотой водицей мудрости.

\section{Пеликаны}

На его берегах встречаю пеликанов. Они узнают меня. Правда, до сих пор опасаются взбалмошной Айдынльг. Как только собака подбегает к ним с приглачением почрать, грациозные пеликаны моментально ретируются, недовольно фыркая. Мол, нас, аристократов, такие игры не забавляют... (Сафарли 2017. 47);

...nрислушиваюсь к еле слышному светскому трепу пеликанов с чайками. Последние жалуются на темперамент Мраморного моря. Он им непонятен. «...Наше море отличается от Босфора. Оно может год быть совершенно спокойным. И вдруг без причины начинает бушевать. Нейтрального состояния у Мраморного нет. Поэтому нам, чайкам, с ним сложно. Не знаем, чего ждать» (Сафарли 2017. 48).

Традиционно наиболее употребляемыми лексемами с олицетворяющими признаками являются глаголы: узнают, опасаются, ретируются, жалуются.

Речь птиц автор персонифицирует с помощью деепричастного оборота недовольно фыркая и определения-персонификатора+имени существительного с антропоморфным признаком светский треп.

В данном примере Э. Сафарли вводит прямую речь птиц, в которой также содержатся антропоморфные характеристики, и олицетворение-приложение пеликаны-аристократьл.

\section{Растительный мир}

Деревья

Основную часть времени посвящал деревьям в саду. Лучшие собеседники. Выслушивали, кивали листьями, ничего не требуя взамен (Сафарли 2017. 244); 
Гордился своими деревьями. Некогда жалкие саженщы на глазах взрослели, приобретали могучие стволь (Сафарли 2017. 246);

«... Вы, дети столицы, не будете возиться с обычными для вас деревьями... Лучше пусть умрут со мной». Когда Джалал-деде произносил эти слова, слышал плач деревьев. Боялись потерять покровителя. Боялись потерять жизнь (Сафарли 2017. 246).

Персонифицированный образ деревьев вводится с помощью олицетворения-приложения деревья-собеседники. Развернутое олицетворение создается с помощью следующих грамматических структур:

Деревья выслушивали / кивали / взрослели / умрут / боялись потерять - предикативные двучленные синтагмы;

Ничего не требуя взамен - олицетворяющий деепричастный оборот;

Плач деревьев - генитивная конструкция.

\section{Растения}

Растения в тексте романа предстают в виде живых существ, которые так же имеют право на жизнь:

Больно получать столь прекрасные создания мертвыми. Когда дарят сорванные тюльпаны, будто удар в спину наносят. Значит, ради моего дня рождения их лишили жизни?... (Сафарли 2017. 89).

В данном развернутом олицетворении автор использует определениеперсонификатор и антропоморфный предикат.

«Эмоциональность» растений представлена с помощью двучленных предикативных и атрибутивных синтагм:

Красные тюльпаны ждут тебя... (Сафарли 2017. 59) антропоморфный признак выражен глаголом состояния; 
Запомни одно. Свежий овощ улыбается тебе, а не умоляет купить его»... (Сафарли 2017. 209) - антропоморфные признаки выражены глаголами действия;

Тем временем Гюльбен занята рисом. «Волиебные зернышки, не любящие спешки» (Сафарли 2017. 237) - антропоморфный признак выражен причастием.

\section{Небесные светила}

\section{Луна}

Образ луны персонифицируется с помощью олицетворения-приложения (царицุа ночного Стамбула луна) и перифразы, которая несет в себе олицетворяющее сравнение: цุарицุа ночи, цุарицฺа, злюка.

...Царища ночного Стамбула луна. Она везде разная. В Москве немного зловещая [...], в Таиланде - чересчур беспокойная. Стамбульская луна умиротворенная (Сафарли 2017. 55);

Грубые космические бульюники облетают царицу ночи стороной. Она защчищена. Защчищена сотнями любящих сердец. Их тепло заставляет луну забыть о собственном небесном одиночестве (Сафарли 2017. 55);

Потому что она могущественна. Она ирарица - недосягаемая, властная, сильная. Стамбульская луна легким движением руки правит босфорской водой. Вызывает приливы, отливы (Сафарли 2017. 56);

«Лучше бы подсказал, как загнать злюку [луну] за толстые облака» (Сафарли 2017. 56).

Олицетворяющие признаки находим в именах прилагательных (зловещзая, беспокойная, умиротворенная, могущественна, властная, сильная), и глаголе забыть, который указывает на наличие ментальной сферы у небесного 
объекта. Также обратим внимание на деталь, указывающую на человеческую внешность луны - луна легким движением руки.

\section{Звезды}

... Под конеи вечера всей компанией вываливаемся на балкон, взглянуть на подмигивающие нам звезды. Одна из них, сделав кувырок в ночном небе, устремляется вниз (Сафарли 2017. 82).

В данном примере автор указывает на наличие у звезд мимики (подмигивающие - атрибутивная двучленная синтагма) и характерного для человека телодвижения (сделав кувырок - дистантное олицетворение с деепричастным оборотом).

\section{Солнце}

Небесное светило обладает человеческими эмоциями, которые передаются с помощью двучленных предикативных синтагм с глаголами ненавидит и осуждает:

\section{Захвати солние с собою. Оно больше не нужно. Оно ненавидит. Оно} осуждает (Сафарли 2017. 185).

Образ солнца создается также с помощью дистантного олицетворения, представленного предлогом и именем существительным, содержащим олицетворяющий признак:

Гордость городка - сахарно-сочные арбузы. Растут под опекой палящего солнияа... (Сафарли 2017. 211).

Таким образом, в романе Э. Сафарли «Сладкая соль Босфора» выделяем следующие виды олицетворяющих структур: 
Предикативная двучленная синтагма включает в себя существительное - денотат олицетворения и персонификатор - слово, содержащее олицетворяющий признак. В романе Э. Сафарли выделяем олицетворяющие предикативные синтагмы, в которых сказуемое-персонификатор представлено в структуре простого глагольного сказуемого, например пойраз ульбается, красньле тюльпань ждут и др.; составного глагольного сказуемого ветер спешит о чем-то поведать, чайки не хотят отлетать и составного именного сказуемого осень за справедливость, дельфинь не в обиде и др.

Атрибутивные двучленные синтагмы в тексте представлены конструкциями трех типов. В первом типе атрибутивных двучленных синтагм антропоморфный признак содержится в согласованном определении, выраженном именем прилагательным, например: Босфор одинок, пойраз недоверчив, сентиментальная кочечка, разъяренные волны и др. Олицетворяющий признак может быть выражен причастием: подмигивающие звезды или причастным оборотом чайки, вальсирующие над синеющим Босфором / волшебные зернышки, не любящие спешки.

Второй тип атрибутивной двучленной синтагмы представляют олицетворения-приложения: кошки-богини, Айдынльг-богиня, друзья-изапли, деревья-собеседники и др.

К третьему типу атрибутивной двучленной синтагмы относим олицетворения в составе генитивных конструкций: плач деревьев.

Как дистантные олицетворения рассматриваем такие олицетворяющие конструкции, в которых антропоморфный признак сочетается с персонифицированным денотатом дистантно через неантропоморфный глагол. Дистантные олицетворения представлены следующими группами грамматических конструкций:

- олицетворяющие наречия: Мястам напутственно мяукает, Айдынльг восхищенно лает. 
- олицетворяющие предложно-падежные формы имени существительного: Босфор бесится от злости, молодые журавлики шумят от радости и др.

- олицетворяющие деепричастия/деепричастные обороты: «... дуется Босфор, хмурясь, как обиженный ребенок», «одна из них [звезд], сделав кувырок в ночном небе, устремляется вниз» и др.

Примеры олицетворяющих сравнений уже упоминались, но добавим, что наиболее часто они вводятся с помощью союза как, а также союза словно и слова похожий. В роли образа сравнения выступает человек (ребенок, мужчина, брюнетка, телохранители), исключение составил лишь один пример, где в качестве образа используется животное (щенок-лабрадорчик).

Иногда в роли предмета олицетворения выступает не сам объект или явление природы, а его признак. Анализ олицетворений природы позволяет выделить, что довольно часто автор персонифицирует звуки природы. Олицетворяющий компонент содержится:

- в существительном, номинирующем звуки природы: недовольное пыхтение Босфора, воркование берега с песком, светский треп пеликанов.

- в глаголах: ветер шепчет, пойраз шипит.

- в деепричастиях: пеликаны недовольно фыркая.

- олицетворяющие признаки содержатся также в именах прилагательных и наречиях: недовольное пыхтение, недовольно фыркая, восхищенно лает.

\section{Заключение}

Для изображения природы в романе «Сладкая соль Босфора» автор широко использует олицетворение и персонификацию. Персонифицированными 
являются образы Босфора, ветра, осени и луны. Общими чертами считаем наличие эмоций, возможность исполнять действия свойственные человеку, реальные очертания внешности (антропоморфные признаки), наличие характера, основные черты которого описывает автор, а также речь. Она превращает данные образы в полноправных персонажей произведения с особой ролью в его структуре и их личной точкой зрения.

Большинство проанализированных нами олицетворений являются развернутыми и включают не один, а несколько антропоморфных признаков, выраженных сходными или различными грамматическими способами. В романе «Сладкая соль Босфора» представлено 65 олицетворяющих контекстов в рамках концепта «природа», в которых выделяем следующие грамматические конструкции: предикативные двучленные синтагмы, атрибутивные двучленные синтагмы, дистантные олицетворения, олицетворяющие сравнения.

Анализ приведенных примеров свидетельствует о том, что наиболее часто предметом олицетворения становятся сами объекты и явления. В связи с этим внимание писателя фокусируется на их эмоциональной и ментальной сфере. К признакам, которые наиболее часто олицетворяются автором, относим звуки природы, внешний вид и жесты.

Таким образом, частота использования тропа олицетворения и разнообразие выделенных нами грамматических структур свидетельствуют о его эффективности в процессе построения тропеической системы текста, а также о важной роли олицетворения в создании ярких художественных образов.

\section{Литература}

1- Голуб И.Б. (2010). Стилистика русского языка. - М.: Изд-во «Айрис-пресс». 
2- Зозуля М.А. (2011). Метафора-персонификаичи в романах В. Голдинга: лингвокогнитивный аспект: автореф. дисс. ... канд. филол. наук: 10.02.04. Донецк: Изд-во «Донец. нац. ун-т».

3- Иванова Л.П. (2013). Лингвоимагология как синтезирующее направление современного языкознания // Беларусско-русско-польское сопоставительное языкознание, литературоведение, культурология: сборник научных трудов. Витебск: Изд-во «ВДУ им. П.М. Машерова».

4- Константинова С.К. (2005). Семантика олищетворения. - Курск: Изд-во «Курский гос. ун-т».

5- Кузнецов С.А. (2000). Большой толковый словарь русского языка / Сост. и гл. ред. С.А. Кузнецов. - СПб.: Изд-во «Норинт».

6- Парсамов С.С. (2004). Персонификация водной стихии в народной мифологии. - Кировоград: Изд-во «КОД».

7- Сафарли Э. (2017). Сладкая соль Босфора. М.: Изд-во «АСТ».

8- Степанов Ю.С. (1995). Изменчивый «образ языка» в науке ХХ века // Язык и культура конца ХХ века. - М.: Изд-во «Наука».

9- Эпштейн М.Н. (1990). «Природа, мир, тайник вселенной...»: система пейзажных образов в русской поэзии. - М.: Изд-во «Высшая школа».

\section{Bibliography}

10- Golub I.B. (2010). Stilistika russkogo jazyka. - M.: Izd-vo «Ajris-press».

11- Zozulja M.A. (2011). Metafora-personifikacija $v$ romanah V. Goldinga: lingvokognitivnyj aspekt: avtoref. disc. ... kand. filol. nauk: 10.02.04. - Doneck: Izdvo «Donec. nac. un-t».

12- Ivanova L.P. (2013). Lingvoimagologija kak sintezirujushhee napravlenie sovremennogo jazykoznanija // Belarussko-russko-pol'skoe sopostavitel'noe jazykoznanie, literaturovedenie, kul'turologija: sbornik nauchnyh trudov. - Vitebsk: Izd-vo «VDU im. P.M. Masherova».

13- Konstantinova S.K. (2005). Semantika olicetvorenija. - Kursk: Izd-vo «Kurskij gos. un-t».

14- Kuznecov S.A. (2000). Bol'shoj tolkovyj slovar' russkogo jazyka / Sost. i gl. red. S.A. Kuznecov. - SPb.: Izd-vo «Norint».

15- Parsamov S.S. (2004). Personifikacija vodnoj stihii v narodnoj mifologii. Kirovograd: Izd-vo «KOD».

16- Safarli Je. (2017). Sladkaja sol' Bosfora. M.: Izd-vo «AST». 
17- Stepanov Ju.S. (1995). Izmenchivyj «obraz jazyka»v nauke HH veka // Jazyk i kul'tura konca HH veka. - M.: Izd-vo «Nauka».

18- Jepshtejn M.N. (1990). «Priroda, mir, tajnik vselennoj...»: cistema pejzazhnyh obrazov v russkoj pojezii. - M.: Izd-vo «Vysshaja shkola».

\section{HOW TO CITE THIS ARTICLE}

Брык M. M. (2020). The Personification of the Nature in the Novel "Sweet Salt of Bosphorus" By E. Safarli Issledovatel'skiy Zhurnal Russkogo Yazyka I Literatury, 8(1), 217-241.

DOI: $10.29252 /$ iarll.15.217

URL: http://www.iournaliarll.ir/index.php/iarll/article/view/117

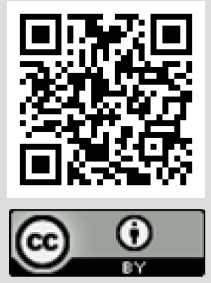


شخصيت بردازى طبيعت در رمان ا. صفرلى ((نمك شيرين بسفر)"

$$
\begin{aligned}
& \text { مارينا مورمانوونا بريك' } \\
& \text { دانشجوى دكترى گروه زبانشناسى همخانى و مطالعات كشورهاى آلمانىزبان، }
\end{aligned}
$$

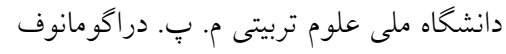

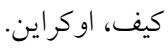

$$
\begin{aligned}
& \text { (تاريخ دريافت: آوريل 19.؟؛ تاريخ بذيرش: نوامبر 19.ب) }
\end{aligned}
$$

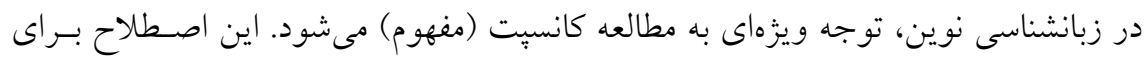

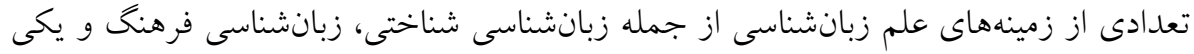

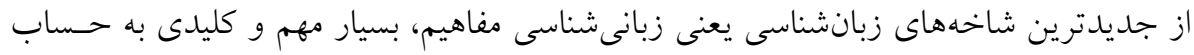

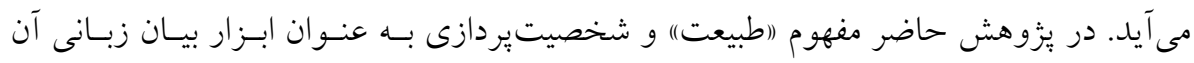

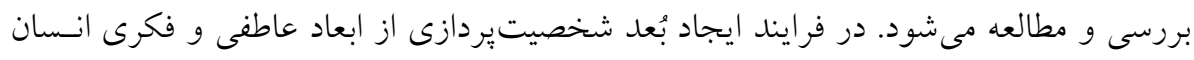

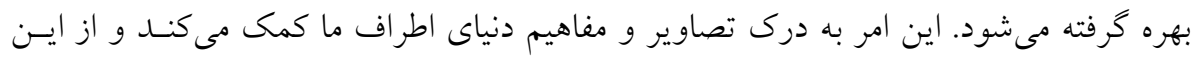

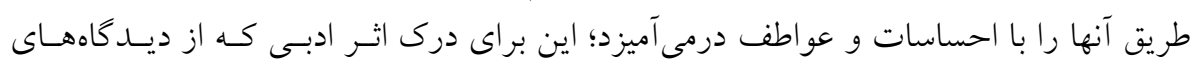

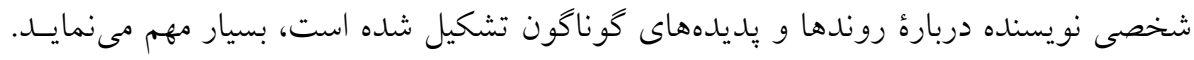

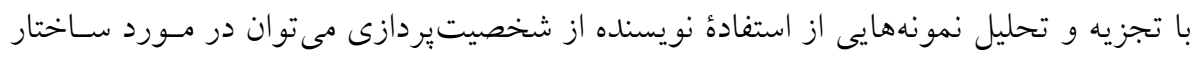

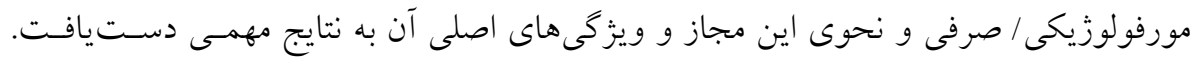

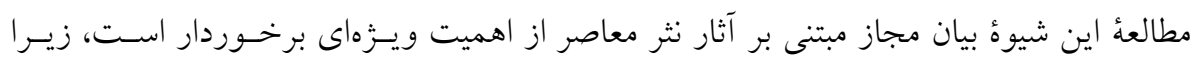

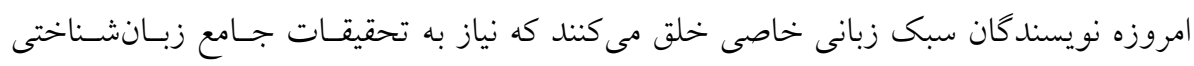

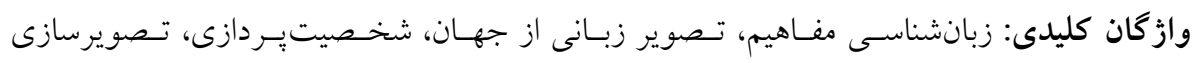

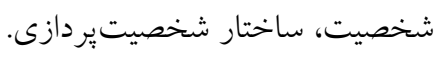

